\title{
La inobservancia al deber de colaboración del acreedor en el derecho chileno: un caso de incumplimiento contractual
}

\author{
Pamela Prado López*
}

\section{RESUMEN}

Es usual que las partes de un contrato deban cooperar para que las obligaciones puedan ser cumplidas. En este trabajo postulamos que un análisis técnico adecuado, supone reconocer que la colaboración del acreedor se erige como un deber secundario o funcional de conducta al interior del contrato, cuya inobservancia constituye un incumplimiento contractual, permitiendo a la contraparte el ejercicio de los remedios contractuales que le franquea la ley.

Colaboración del acreedor - deberes secundarios de conducta incumplimiento contractual

\section{Breach of the duty of cooperation of the creditor in Chilean law: a case of breach of contract}

\begin{abstract}
It is common for parties to a contract must cooperate so that the obligations can be met. In this paper we postulate that proper technical analysis, means recognizing that cooperation creditor stands as a secondary or functional duty of conduct within the contract, breach of which constitutes a breach of contract, allowing the counterparty exercise of contractual remedies.
\end{abstract}

Cooperation creditor - secondary duties of conduct - breach of contract

* Doctora en Derecho, Universidad de Chile. Académica Escuela de Derecho Universidad de Valparaíso. Correo electrónico: pamela.prado@uv.cl.

Este trabajo se basa en una parte de la Tesis doctoral titulada "La colaboración del acreedor en los contratos civiles, de acuerdo al ordenamiento jurídico chileno", y que a la fecha se encuentra publicada por la Editorial Thomson Reuters- La Ley, Santiago de Chile, 2015. Este estudio se enmarca en el Proyecto Fondecyt Inicia $\mathrm{N}^{\circ} 11140155$.

Artículo recibido el 28 de noviembre de 2014 y aceptado para su publicación el 30 de agosto de 2016. 


\section{INTRODUCCIÓN}

$\mathrm{E}$ n las relaciones contractuales es habitual que las partes deban cooperar para que las prestaciones puedan ser cumplidas. De manera más concreta, se ha entendido que en múltiples ocasiones el acreedor tiene el deber de colaborar; así, un caso típicamente citado por los autores extranjeros es la recepción del pago de una obligación de dar que se le ofrece por el deudor, de manera tal que si el acreedor no recibe dicho pago, el primero no podrá liberarse del vínculo obligatorio ${ }^{1}$. Pero fuera de este, hay una serie de situaciones en que las partes deben colaborar, por ejemplo si se contrata a un artista para que confeccione una pintura del mandante y este no concurre a posar, o no le entrega las fotografías que desea que se utilicen para tal efecto; o bien, se encarga a un mecánico la reparación de un automóvil y luego no se pone a disposición para que lo repare. Hay que agregar a aquellos contratos en que atendida su mayor complejidad, la colaboración entre las partes se requiere durante toda su ejecución.

Esta necesidad de que las partes cooperen o colaboren en las relaciones contractuales ha sido recogida de diversas formas por legislaciones extranjeras más recientes y por el derecho uniforme, a diferencia de nuestro ordenamiento jurídico que guarda silencio. De consiguiente, el objetivo de este trabajo es evidenciar que, a pesar de que el derecho civil chileno no consagre en forma expresa a la colaboración del acreedor, es posible argumentar dogmáticamente que en determinados grupos de casos, tal colaboración del acreedor constituye un deber dentro de la relación jurídica contractual, de tal suerte que su inobservancia produce consecuencias jurídicas tanto para el acreedor como para el deudor contractual.

\section{UN CRITERIO ORDENADOR A PROPÓSITO DE LA ESTRUCTURA DEL CONTRATO}

\section{Preámbulo}

Nos parece necesario introducir como un elemento de análisis relevante, la diferenciación entre obligaciones primordiales y deberes secundarios, funcionales o de conducta al interior del contrato, con la finalidad de proponer que la colaboración del acreedor participa de la segunda de dichas calidades. En ese orden, aplicaremos esa diferenciación en el ambiente del contrato bilateral, porque se trata de aquella convención que mayormente se acuerda en el tráfico jurídico, además de erigirse como el modelo contractual por antonomasia en el derecho de contratos.

\footnotetext{
${ }^{1}$ Medicus, D., Tratado de las relaciones obligacionales, Bosch, Barcelona, 1995, pp. 198 ss.
} 


\section{La distinción entre obligaciones primordiales o principales y deberes secundarios o funcionales de conducta}

Nos situaremos en el contrato bilateral, como hemos indicado, atendido que es el que mayoritariamente se utiliza en el tráfico jurídico ${ }^{2}$. Sin perjuicio de ello, hay que precisar que la figura de la colaboración del acreedor también se puede presentar en los unilaterales, de modo que algunas de las conclusiones a que arribemos serán aplicables a estos. En efecto, pensemos en el caso de aquellos contratos en que el deudor está obligado a restituir la cosa objeto de la convención y el acreedor no coopera recibiéndola, o no lo hace en forma oportuna, generando mayores gastos de mantención al deudor, como en un depósito o en un comodato; o en contratos en que el deudor debe cumplir con una obligación de dar, como el donante de donación irrevocable, en que el donatario rechaza la tradición a que el donante se ha obligado.

Ahora bien, en lo que refiere al contrato bilateral debemos hacer una primera constatación, y es que cuando nuestra doctrina más tradicional afronta su estudio, la tendencia es analizarlo a propósito de lo que se ha denominado la teoría general del contrato $^{3}$, para luego centrarse en el estudio de algunos contratos bilaterales en particular; en este último caso, el esquema que se sigue usualmente es identificar a la o las obligaciones que asumen cada uno de los contratantes.

Sin embargo, esta mirada al contrato bilateral se aleja de su funcionamiento práctico, entre otras razones, porque se pasa por alto la íntima vinculación que, de ordinario, se produce entre todas las obligaciones que nacen del acuerdo ${ }^{4}$, obviando así un examen sistémico y, por tanto, realista del contrato bilateral. Esta rígida estructura contractual con que se suele abordar al contrato sinalagmático, supone que se encuentra perfectamente determinada la calidad de deudora o acreedora de cada parte desde el inicio de la relación jurídica, para ello solo se consideran las obligaciones más características de cada contrato, sin tomar en consideración lo que ocurra durante la vigencia del mismo. Pero la contratación contemporánea no siempre obedece de manera tan prístina a este esquema, pues en el contrato se difuminan las calidades de deudor y acreedor que ostentaría cada parte, desvanecimiento que se produce, fundamentalmente, debido al contenido del mismo ${ }^{5}$, entendiendo por contenido del contrato, como dice Díez Picazo,

${ }^{2}$ Colin, A. y Capitant, H., Curso elemental de derecho civil. Teoría general de las obligaciones, Reus S.A., Madrid, 1987 , p. 725.

${ }^{3}$ López, J., Los contratos. Parte general, Editorial Jurídica de Chile, Santiago, 1988, p. 80. Alessandri, A., De los contratos, Editorial Jurídica de Chile, Santiago, 2010, p. 18.

${ }^{4}$ Salvo cuando se reconoce que las obligaciones de una parte están interrelacionadas con las de la otra, para efectos de justificar lo que se ha venido en denominar "efectos particulares de los contratos bilaterales". Así, López, J., cit., pp. 411-412.

5 Terminología muy utilizada, como se corrobora de lo que establece el artículo 2 del Código Europeo de contratos de la Academia de Pavía, que dispone: "Autonomía contractual. 1. Las partes pueden determinar libremente el contenido del contrato, dentro de los límites de impuestos por las reglas imperativas, las buenas costumbres y el orden público, tal y como vienen definidos en el presente Código, en el Derecho comunitario o en las leyes nacionales de los Estados miembros de la Unión europea, siempre que no persigan 
a "la composición misma del contrato, su sustancia más íntima y entrañable" 6 , por ello es que el verdadero contenido contractual está constituido por las reglas de conducta. Los contratantes más que declarar una voluntad "se comprometen"; los poderes y deberes son los efectos del contrato, el contenido del contrato es la formulación, la regla que establece o estatuye estos deberes y estos poderes ${ }^{7}$. Así, es posible identificar el contenido del contrato con la reglamentación contractual, esto es, con las reglas de conducta y "cualesquiera otras determinaciones jurídicamente relevantes contenidas en las cláusulas contractuales" 8 .

En esa línea, nos parece que para determinar de forma apropiada el contenido del contrato es posible recurrir a la distinción entre obligaciones principales o primordiales de la convención, y deberes que tienen un carácter funcional, en tanto permiten que las primeras se obtengan. Esta diferenciación de los roles que cumplen las diversas prestaciones al interior del contrato no es nueva, como se evidencia de los postulados de la doctrina, especialmente europea. En efecto, ya sea a propósito del estudio del alcance de la relación obligatoria, de los efectos de la buena fe, u otros tópicos, los autores han intentado resolver el problema de la extensión de los deberes del deudor y, luego, llevar a cabo una sistematización de estos. Con todo, se trata de un esquema que no ha tenido mayor acogida en la doctrina nacional más clásica, con alguna excepción?

Entre los juristas extranjeros es reiterada la alusión a esta estructura contractual. Así, se ha distinguido, de acuerdo con el criterio de la exigibilidad en juicio, entre: obligaciones integrativas instrumentales, y obligaciones integrativas primarias, que tienen una finalidad auxiliar, pero con existencia propia, y, por tal razón, que son exigibles por sí mismas ${ }^{10}$. Las primeras se caracterizarían porque están estrechamente vinculadas a la prestación debida y, como tales, no pueden separarse de ella bajo ningún respecto, como la obligación de custodia que tiene el deudor de obligación de entrega de una cosa debida $^{11}$. Las segundas serían obligaciones primarias con el carácter de auxiliar por sí y que, por consiguiente, son exigibles por sí mismas, como el caso de la obligación de denuncia de defectos en los materiales suministrados en el contrato de arrendamiento

únicamente el fin de perjudicar a otros”. Rogel, C. (coordinador), Código europeo de contratos. Libro I: De los contratos. Libro II, Título I: De la compraventa, Editorial Reus S.A., Madrid, 2009, p. 9.

${ }^{6}$ Díez Picazo, L., Fundamentos del derecho civil patrimonial. I Introducción Teoría del contrato, Civitas, Thomson Reuters, Madrid, 2009, pp. 448-449. Agrega que la doctrina tiende a pensar que el contenido son las obligaciones contractuales, pero la denominación de "obligaciones contractuales es equívoca, pues se entiende por ello al menos tres cosas: deberes contractuales; la correlación entre los deberes contractuales y el poder contractual de la otra; y la totalidad de la relación jurídica, con todos los deberes y poderes del contrato".

${ }^{7}$ Díez Picazo, L., cit., p. 450.

${ }^{8}$ Martínez de Aguirre, C., en Cámara, S. (coord.), Derecho privado europeo, Colex, Madrid, 2003, p. 439.

${ }^{9}$ Entre dichas excepciones, Ducci, C., "La culpa del acreedor en la responsabilidad contractual", en Tavolari, R. (coord.), Doctrinas esenciales de derecho civil. Obligaciones, Editorial Jurídica de Chile, Santiago, 2009, pp. 495-496.

${ }^{10}$ Betti, E., Teoría general de las obligaciones, Editorial Revista de derecho privado, Madrid, 1969, pp. 106-108.

${ }^{11}$ Betti, E., cit., pp. 107-108. 
de obras ${ }^{12}$. Hay autores que hablan de "deberes agregados", como la variable del deber de información que, según Hedemann, acompaña a muchas relaciones de crédito y que viene exigida por la buena fe; un ejemplo es la rendición de cuentas en el mandato que, a la vez, constituiría un caso especial de deber de información; también el abono de gastos, que sería un fenómeno concomitante con la liquidación de la relación obligatoria $^{13}$. Entre los casos que se reconocen como manifestación de estos deberes particulares de conducta se ha identificado a aquel según el cual "el acreedor está obligado, al menos en tanto el deudor tenga en ello un interés digno de protección, a no impedir la prestación del mismo, y a hacerla posible en tanto esta dependa de él" ${ }^{\prime 4}$, coherente con el planteamiento de este trabajo.

La doctrina española es especialmente prolífica en esta clase de análisis, especialmente al estudiar el contenido de la relación obligatoria, a la que se adicionan no solo deberes sino también cargas, así en la situación jurídica del deudor es posible identificar tanto al deber o deberes primarios como deberes accesorios ${ }^{15}$.

${ }^{12}$ Betti, E., cit., p. 108. Con todo, hay que advertir que Betti no le confiere mayor relevancia a este tipo de distinciones, que califica de extrínsecas. pp. 105-106.

${ }^{13}$ Hedemann, W., Derecho de obligaciones, Editorial Revista de derecho privado, Madrid, 1958, pp. 51-54. En línea similar, Von Thur comenta que la jurisprudencia y la doctrina han desarrollado el principio de la buena fe en varias direcciones, y a vía ejemplar menciona la creación de particulares deberes de conducta que se despliegan tanto en la "preparación de la prestación propiamente dicha, a la forma de su ejecución, a la cooperación eventualmente necesaria de ambas partes y a la consideración que según la equidad puede cada parte esperar de la otra en semejante relación. Von Thur, A., Tratado de las obligaciones, Editorial Comares S.L., Granada, 2007, p. 154.

${ }^{14}$ Von Thur, A., cit., p. 155. A su turno, en lo que respecta a la posición de la parte deudora, ella efectivamente aparece primeramente como un deber de realizar una prestación a otra persona, que sería "el deber central y primario del deudor, sobre esto no cabe duda de ningún género, es el deber de realizar la prestación, es decir, el deber de desplegar aquella conducta o aquel comportamiento en que la prestación consiste".

${ }^{15}$ Díez Picazo, L., "El contenido de la relación obligatoria”, Separata, Instituto Nacional de Estudios Jurídicos, en Anuario de derecho civil, fasc. II 1964, pp. 258 y 353. En lo que respecta a la posición de la parte deudora, Díez Picazo agrega que efectivamente aparece primeramente como un deber de realizar una prestación a otra persona, que sería "el deber central y primario del deudor, sobre esto no cabe duda de ningún género, es el deber de realizar la prestación, es decir, el deber de desplegar aquella conducta o aquel comportamiento en que la prestación consiste”. Pero además, hay ciertos deberes accesorios o secundarios encaminados a proporcionar al acreedor un bien económicamente valioso para que se vea satisfecho su interés, que pueden ser de la más variada naturaleza, a veces son de origen legal; otros de carácter convencional; pueden emanar de los usos de los negocios; o bien, derivados de la buena fe. Adiciona que algunos de ellos pueden formar parte de la misma prestación primaria, si no alcanzan a adquirir entidad suficiente; y otros adquieren independencia de la prestación principal, erigiéndose como una nueva prestación de naturaleza accesoria que, de infringirse, dará lugar a una situación de cumplimiento imperfecto. pp. 361-362. Similar a este análisis, García, M., Lecciones de derecho civil II. Teoría general de las obligaciones y contratos, McGraw-Hills, Madrid, 1995, pp. 439-440. Albaladejo, M., Derecho civil II. Derecho de obligaciones, Edisofer S.L., Madrid, 2004, p. 33. Morales, A., Incumplimiento y lucro cesante, Civitas, Madrid, 2010, p. 88. Este último refiere a la existencia de diversos tipos de deberes que integran la relación obligatoria, distinguiendo entre deberes de prestación y deberes de protección o de cuidado; los primeros son los que tienen por finalidad la satisfacción del interés en la realización o cumplimiento del contrato. 
Entonces, un criterio ordenador y orientador acerca del contenido del contrato que tiene directa incidencia en la determinación de los deberes de conducta a que se someten las partes ${ }^{16}$, es sustentar que la estructura contractual está constituida tanto por prestaciones principales a que estas se comprometen como por otros deberes de carácter funcional que permiten que las prestaciones principales se obtengan. Las prestaciones principales o primordiales del contrato son aquellas que efectivamente los contratantes persiguen obtener, son la razón por la que han concluido la relación contractual, en tanto que los deberes secundarios de conducta son de naturaleza funcional, pues tienen por objeto que las prestaciones principales se cumplan, de modo que se obtenga el fin último perseguido por el contrato.

Por tanto, nuestro postulado es que el deber de colaboración del acreedor constituye un deber secundario o funcional, ya que permite a las partes obtener el cumplimiento de las principales prestaciones del contrato. La característica especial que este presenta, empero, es que se trata de un deber secundario o funcional que tiene por finalidad que el otro contratante pueda, a su turno, ejecutar sus prestaciones principales o primordiales, como se verá a continuación.

\section{Apuntes Sobre la NATURALEZa de la COLABORACión DEL ACREEDOR EN EL DERECHO CIVIL}

\section{Respecto del propósito de analizar la naturaleza jurídica de la colaboración del acreedor}

Resulta esencial dar un vistazo al problema de la naturaleza de la colaboración del acreedor, no solo porque se trata de un aspecto imposible de soslayar en cualquier estudio de este carácter, sino muy especialmente porque los autores foráneos han transitado entre dos opiniones: o es una carga contractual, o constituye un deber al interior del contrato. Adoptar una u otra posición repercute directamente en las consecuencias derivadas de su inobservancia. Nuestra opinión, como hemos anticipado, es que la colaboración del acreedor es un deber secundario o funcional al interior del contracto.

\section{El derecho extranjero y uniforme: una mirada panorámica}

Como hemos indicado, la colaboración del acreedor no constituye una figura reciente, por el contrario, los juristas extranjeros le han dado una gran relevancia, especialmente en lo que refiere a las consecuencias que se producen si el acreedor no despliega dicha cooperación. La doctrina foránea, en especial la europea, además de aproximarse a la colaboración del acreedor a propósito de temáticas generales, ha elaborado varios estudios

${ }^{16}$ Con esta estructura no se descarta, por cierto, el mayor alcance que hoy se reconoce a la relación obligatoria, en tanto en virtud de esta no solo se imponen deberes de conducta a las partes, sino también "la garantía, a cargo del deudor, de satisfacción de un determinado interés del acreedor; es decir, la garantía de ese resultado”. Morales, A., La modernización del derecho de obligaciones, Civitas, Madrid, 2006, p. 19. 
cuyo preciso objeto es analizarla. De estos estudios interesa resaltar que no hay consenso acerca de la naturaleza jurídica que tiene dicha colaboración. En efecto, hay aquellos que sustentan que la cooperación del acreedor constituye una verdadera obligación, como es el caso de Falzea, de modo que además de los efectos propios de la mora del acreedor, se permite al deudor exigir al acreedor su cumplimiento, y si este no cumple, se genera un caso de incumplimiento contractual ${ }^{17}$. Para otros, en cambio, constituye siempre una carga contractual, como es la opinión de Cattaneo, que aunque reconoce que es un fenómeno muy frecuente, su inobservancia solo generaría mora del acreedor ${ }^{18}$. También de carga la califica Cabanillas Sánchez ${ }^{19}$. En un tercer grupo, se sitúan aquellos autores que tienen una opinión matizada, esto es, que atendida las circunstancias, a veces tiene la naturaleza de carga y otras de deber al interior de la relación obligatoria, como Caballero Lozano ${ }^{20}$ y Lamarca ${ }^{21}$.

Los postulados de la doctrina europea han llevado, además, a un paulatino reconocimiento a la figura de la colaboración o cooperación del acreedor, tanto por algunas legislaciones como por el derecho uniforme.

En lo que toca a los derechos internos, la tendencia ha sido reconocer en forma progresiva la necesidad de que el acreedor colabore o coopere con el cumplimiento del deudor, especialmente al reglamentar la mora creditoris. Así, en forma incipiente se aprecia la importancia de la colaboración del acreedor en el CC italiano de 1942, la que se encuentra tratada a propósito de la mora del acreedor en el art. 1206, en la norma siguiente se regulan los efectos de la mora ${ }^{22}$.

${ }^{17}$ Falzea, A., Angelo, La’ oferta reale e la liberazione coattiva del debitore, Giuffré, Milán, 1947, pp. 77 s.

18 Cattaneo, G, La cooperazione del creditore all'adempimento., Dott. A. Giuffre-Editore, Milán, 1964, pp. 27 s. y 47.

19 Para Cabanillas, la colaboración del acreedor constituye una carga contractual de aquellas que denomina heterónomas, distinguiendo entre la carga de facilitación de la liberación del deudor, y la de colaborar para que el deudor pueda ejecutar la prestación. Cabanillas, A., Las cargas del acreedor en el derecho civil y mercantil, Editorial Montecorvo, S.A., Madrid, 1988, pp. 72 ss. y 204 ss.

20 "Lo que no nos parece tan seguro que, a tenor de lo expuesto, es que la cooperación del acreedor al cumplimiento sea una auténtica carga que acompañe al derecho al crédito. A nuestro entender, calificar de carga la conducta del acreedor antes citada supone un olvido del interés del deudor en la obligación, que no por ser de menos rango queda desprotegido. La cooperación del acreedor al cumplimiento es una conducta también en interés del deudor, ya que a este no le es indiferente cumplir o no su obligación. En este sentido, la falta de cooperación no queda sin sanción como sucedería de ser una carga en sentido técnico; antes bien, el ordenamiento prevé la mora creditoris y la consignación judicial -figura de la que no está del todo ausente la idea de ejecución coactiva- como medidas tendientes a neutralizar los efectos negativos de la inobservancia de dicha carga. Si el acreedor no coopera, no solo no deja ocioso su crédito sino que también perjudica los justos derechos y expectativas del deudor. La libertad que tiene el acreedor de verificar la carga solo se entiende en el caso que nos ocupa si consideramos que el deudor es también libre de cumplir su obligación”. Caballero, J., La mora del acreedor, Bosch Editor S.A., Barcelona, 1992, p. 127.

${ }^{21}$ Lamarca, A., El hecho del acreedor y la imposibilidad de la prestación, Publicaciones del Real Colegio de España, Bolonia, 2001, p. 64.

${ }^{22}$ Art. 1206. Il creditore è in mora quando, senza motivo legittimo, non riceve il pagamento offertogli nei modi indicati dagli articoli seguenti o non compie quanto è necessario affinché il debitore possa adempiere l'obbligazione (att. 160).

Art. 1207. Quando il creditore è in mora, è a suo carico l'impossibilità della prestazione sopravvenuta per causa non imputabile al debitore (1256 e seguenti, 1673). Non sono più dovuti gli interessi né i frutti 
El CC portugués de 1966 sigue esta misma tendencia de positivar a la colaboración dentro de la regulación de la mora creditoris $^{23}$.

En otras legislaciones no hay mención expresa a la colaboración del acreedor, como en el BGB, sin embargo, la reforma del 2001 modificó el §241, incorporando un párrafo $(2)^{24}$, que agrega a la relación obligatoria el respeto de los derechos, bienes jurídicos e intereses de la otra parte, de manera que la noción amplia de colaboración del acreedor, que se manifiesta en una gran variedad de comportamientos que este debe desplegar, emerge como un deber dentro de la relación contractual, como ha admitido la doctrina más autorizada ${ }^{25}$, lo que queda corroborado por la también amplísima norma contenida en el $\S 280$, sobre resarcimiento de daños por incumplimiento de un deber ${ }^{26}$.

Algo similar es posible predicar en el ámbito latinoamericano. A vía ejemplar, el CC peruano de 1984 no trata en forma expresa a la colaboración del acreedor, pero se infiere del art. 1155 referido a las obligaciones de hacer que regula la imposibilidad de la prestación por culpa del acreedor ${ }^{27}$; también se le aprecia respecto de las obligaciones de dar a propósito de la teoría del riesgo en las obligaciones de dar especie o cuerpo cierto, art.1138, regla tercera, pues de esa norma se colige la necesidad de que el acreedor concurra a la entrega de la cosa que le ofrece su deudor ${ }^{28}$; a la vez, que el

(820) della cosa che non siano stati percepiti dal debitore. Il creditore è pure tenuto a risarcire i danni derivati dalla sua mora (1224) e a sostenere le spese per la custodia e la conservazione della cosa dovuta. Gli effetti della mora si verificano dal giorno dell'offerta, se questa è successivamente dichiarata valida con sentenza passata in giudicato (Cod. Proc. Civ. 324) o se è accettata dal creditore.

23 Artículo 813, "O credor incorre em mora quando, sem motivo justificado, não aceita a prestação que lhe é oferecida nos termos legais ou não pratica os actos necessários ao cumprimento da obrigação.

${ }^{24}$ La norma dispone: "\$241 Deberes de la relación obligatoria. (1) En virtud de la relación obligatoria el acreedor está legitimado para reclamar una prestación del deudor. La prestación puede consistir también en una omisión. (2) La relación obligatoria, de acuerdo con su contenido, puede obligar a cada parte a respetar los derechos, bienes jurídicos e intereses de la otra parte”.

${ }^{25}$ Markesinis, B., Unberath, H., y Jonhston, A., Markesinis, B., Unberath, H., Jonhston, A., The german law of contract. A comparative, traitase., Hart Publishing, Oxford, Portland, Oregon, p. 128.

${ }^{26}$ Aunque algunos autores, al analizar la incorporación del $§ 241$ (2), hablan de deberes de protección, en oposición a los deberes de prestación, incluyen tanto deberes de acción como de omisión, todos estos permiten el cumplimiento de los deberes principales, así, quedarían incorporados deberes como los de información, de denuncia, de orientación, de asesoramiento, de advertencia, de revisión, etc. Ehmann, H., y Sutschet, H., Modernización del derecho alemán de obligaciones, Universidad Externado de Colombia, Bogotá, 2006, p. 107.

${ }^{27}$ Art. 1155 que establece: "Si la prestación resulta imposible por culpa del acreedor, la obligación del deudor queda resuelta, pero este conserva el derecho a la contraprestación, si la hubiere.

Igual regla se aplica cuando el cumplimiento de la obligación depende de una prestación previa del acreedor y, al presentarse la imposibilidad, este hubiera sido constituido en mora.

Si el deudor obtiene algún beneficio con la resolución de la obligación, su valor reduce la contraprestación a cargo del acreedor".

${ }^{28}$ Art. 1138 "Teoría del riesgo en las obligaciones de dar bien cierto. No 3 Si el bien se pierde por culpa del acreedor, la obligación del deudor queda resuelta, pero este conserva el derecho a la contraprestación, si la hubiere. Si el deudor obtiene algún beneficio con la resolución de la obligación, su valor reduce la contraprestación a cargo del acreedor". 
art. 1338 regula la mora del acreedor ${ }^{29}$. Hay que destacar que la norma que sigue establece la indemnización que debe el acreedor a su deudor, debido a los daños que ocasione a este el retraso del acreedor.

Con todo, si bien existe una relación entre la colaboración del acreedor y la figura de la mora creditoris, nos parece que esta última figura aborda solo un aspecto de la colaboración del acreedor, y más específicamente de su inobservancia, ya que únicamente refiere a las consecuencias derivadas de dicha inobservancia en el plano del destino de la o las obligaciones que el deudor no pudo cumplir íntegra y oportunamente debido a que el acreedor no cooperó, y no pone énfasis en la configuración de un incumplimiento contractual para el acreedor en caso que no colabore, debiendo hacerlo. Volveremos acerca de este punto. En el derecho uniforme, la colaboración que deben prestar las partes en el contrato se encuentra expresamente reconocida en algunos instrumentos normativos. Entre ellos, el art.5.1.3 de los Principios de UNIDROIT que establece: "cada una de las partes debe cooperar con la otra cuando dicha cooperación pueda ser razonablemente esperada para el cumplimiento de las obligaciones de esta última" ${ }^{30}$. Los comentarios a los Principios expresan que hay dos manifestaciones de la cooperación: la primera se refiere al deber de no obstaculizar el cumplimiento de la otra parte; y la segunda, una cooperación activa entre los contratantes ${ }^{31}$. En el art. 1:202 de los PECL se consagra el deber de colaboración, en los siguientes términos: "Cada parte tiene el deber de colaborar con la otra para que el contrato surta plenos efectos". A diferencia de los Principios de UNIDROIT, aquí derechamente se califica a la colaboración como un deber que emana del contrato. En los comentarios de los PELC se destaca que este deber incluye el de permitir que la otra parte cumpla con sus obligaciones para así obtener los frutos de la prestación pactada en el contrato, lo que explica especialmente mediante el siguiente ejemplo: "Ejemplo 1: S, que se encuentra en Hamburgo, acuerda vender mercancías a B, que se encuentra en Londres, a un precio pactado en Hamburgo. B no designa qué buque deberá transportar las mercancías. Ello constituye un incumplimiento de las obligaciones de $\mathrm{B}$ derivadas del contrato de compraventa y también infringe este artículo, porque impide que $\mathrm{S}$ cumpla su obligación de embarcar las mercancías y que obtenga el precio pactado en el contrato. S queda liberado de su cumplimiento conforme al art. 8:101 (3)

${ }^{29}$ Art. 1338: "El acreedor incurre en mora cuando sin motivo legítimo se niega a aceptar la prestación ofrecida o no cumple con practicar los actos necesarios para que se pueda ejecutar la obligación”.

${ }^{30}$ Principios UNIDROIT sobre los contratos comerciales internacionales 2010, International Institute for the Unification of Private Law, Roma, 2007. p. 150.

${ }^{31}$ Principios UNIDROIT sobre los contratos comerciales internacionales 2010, cit., p. 136. Los comentarios ilustran con los siguientes ejemplos: 1. A, después de haber celebrado con B un contrato para la entrega inmediata de cierta cantidad de petróleo, compra de otra fuente todo el petróleo disponible en el mercado. De esta forma, A obstaculiza el cumplimiento de la obligación de B, lo que es contrario al deber de cooperar entre las partes. El segundo ejemplo es que A, galería de arte del país X, compra una pintura del siglo XVI a B, que es un coleccionista privado del país Y. El cuadro no puede ser exportado del país Y, sino por medio de una autorización especial y el contrato establece que es obligación de B obtenerla. Sin embargo, B carece de experiencia en la realización de estos trámites, por lo que se ve en serias dificultades para obtener la autorización, mientras que A tiene amplia experiencia es este tipo de solicitudes; en este caso, y a pesar de lo que establece el contrato, es razonable esperar que A brinde alguna cooperación a B. 
y puede poner fin al contrato y obtener una indemnización por daños y perjuicios" ${ }^{2}$. Es decir, por las circunstancias del caso que se exponen, es posible visualizar dos grupos de efectos derivados de su infracción: el primero, que no se cumplirá la obligación por S, pues no ha podido hacerlo debido a la inobservancia de la colaboración debida por parte de $\mathrm{B}$, por lo que $\mathrm{S}$ queda liberado del cumplimiento de su propia obligación para con $\mathrm{B}$; pero además, como se ha incumplido el deber de colaboración, S podrá poner fin al contrato y demandar la indemnización de los perjuicios derivados del incumplimiento de B. En suma, la inobservancia del deber de colaboración constituye un incumplimiento contractual que permite a la contraparte valerse de los remedios que el ordenamiento jurídico le proporciona, lo que estará supeditado a que se reúnan los requisitos que establece la ley en cada caso.

Un tratamiento análogo referido a los contratos de servicios, encontramos en los Principles of european law on services contracts -PELSC-, art.1:104, sobre deber de cooperación $^{33}$. Es interesante destacar que en esta norma hay una mayor variedad de manifestaciones del deber de cooperación, acorde con la naturaleza de los contratos que se regulan, por ejemplo: el cliente debe proporcionar la información que ha sido solicitada por el proveedor para que este pueda cumplir; se debe suministrar las instrucciones que el proveedor requiera para proveer el servicio; si es necesario, existe el deber de obtener los permisos y licencias requeridas para que el proveedor pueda ejecutar el contrato. Se resalta, además, que en caso de que el cliente no cumpla con este deber de cooperación y ello provoca daños al proveedor, este puede obtener el resarcimiento de los perjuicios.

${ }^{32}$ Lando. O. y Beale, H., Principios de derecho contractual europeo. Partes I y II. Trabajos de la Comisión de derecho contractual europeo, 2003, p. 158.

33 (1) The duty under Article 1:202 PECL (Duty to Co-operate) requires in particular:

(a) (a) the client to answer reasonable requests by the service provider for information in so far as this is reasonably necessary to enable the service provider to perform the contract;

(b) (b) the client to give directions regarding the performance of the service in so far as this is reasonably necessary to enable the service provider to perform the contract;

(c) (c) the client, in so far as the client is to obtain permits or licenses, to obtain these at such time as is reasonably necessary to enable the service provider to perform the contract;

(d) (d) the service provider to give the client a reasonable opportunity to determine whether the service provider is performing the obligations under the contract; and

(e) (e) the parties to co-ordinate their respective efforts in so far as this is reasonably necessary to perform the contract.

(2) (2) If the client fails to perform the duties under subparagraph (1) (a) or (b), the service provider may either withhold performance under Article 9:201 PECL (Right to Withhold Performance), or base performance upon the expectations, preferences and priorities a person in the same situation as the client may reasonably be considered to have, given the information and directions that have been gathered, provided that the client is warned in accordance with Article 1:110.

(3) (3) If the client fails to perform the duties under paragraph (1) causing the service to become more expensive or to take more time than agreed upon in the contract, the service provider is entitled to:

(a) damages for the loss the service provider sustained as a consequence of the nonperformance; and

(b) an adjustment of the time of performance that is required for the service". Este mismo deber se desarrolla luego, en los artículos 2:102, 3:102 y 5:103, aunque en verdad el deber de colaboración se encuentra ínsito en prácticamente la totalidad de las disposiciones de los PELSC. 
En forma consecuencial, el art. 1:104 del Libro III del MCR, sobre obligaciones y derechos contractuales, recoge el deber de cooperación en términos análogos a los PECL ${ }^{34}$. Hay, sin embargo, alguna crítica al establecimiento de esta norma en el $\mathrm{MCR}^{35}$, pues se afirma que la amplitud de este deber general de cooperación oscurecería la primacía que indudablemente aún se le reconoce a la autonomía privada, agregado al hecho de que a lo largo del mismo MCR hay otras manifestaciones de dicho deber de cooperación, como lo dispuesto en el art. III 1:103 sobre deberes derivados de la buena fe, o los que emanan de un cambio de circunstancias, art. III 1:110. Efectivamente, hay que admitir que la amplitud de las normas anotadas, especialmente la primera de ellas, conlleva el peligro de conferirle al deber de cooperación un alcance extensísimo, como a la buena fe, oscureciendo con ello su sentido y alcance, de ahí la necesidad de perfilar al deber de colaboración en términos más concretos, como es el planteamiento contenido en este trabajo.

Por su parte, también los “Acquis principles” establecen en el Capítulo 7 sobre Cumplimiento, el deber de cooperación ${ }^{36}$.

\section{La colaboración del acreedor en el contrato en la doctrina nacional}

La doctrina chilena se ha aproximado en muy contadas ocasiones a la idea de colaboración o cooperación del acreedor; los autores se han limitado a mencionarla, omitiendo un estudio sistemático de la misma. En efecto, se la ha analizado en forma muy escueta, por ejemplo, a propósito de la mora del acreedor, que se suele ubicar luego de la mora del deudor - y ambas con ocasión del estudio de la acción de indemnización de perjuicios por incumplimiento contractual-; en este caso se citan como normas fundamentales los arts. 1548, 1680 y 1827 del CCCh. Los autores que siguen este patrón acostumbran identificar como una típica manifestación el caso en que el acreedor no recibe el pago ofrecido por el deudor -por ejemplo, si no concurre al lugar acordado en que tal pago se llevaría a cabo- ${ }^{37}$. En la misma línea, aunque con alguna mayor profundidad, el análisis de Rodríguez Grez, que sitúa a la colaboración del acreedor en las que denomina “causales de eliminación del factor de imputación”, entre las que menciona a la fuerza

34 "III.- 1:104: Co-operation. The debtor and creditor are obliged to co-operate with each other when and to the extent that this can reasonably be expected for the performance of the debtor's obligation".

${ }^{35}$ Eidenmuller, H., Faust, F., Grigoleit, H., Jansen, N, Wagner, G., Zimmermann, R., "El marco común de referencia para el derecho privado europeo", en Anuario de derecho civil, Madrid, NoLXII, fasc. IV, 2009, pp. 1488-1489.

36 Art. 7:104 Deber de cooperación. Deudor y acreedor deben cooperar entre sí con el alcance que quepa razonablemente esperar en el cumplimiento de una obligación”. Se agrega, además, en la definición del incumplimiento del artículo 8:101, que hay incumplimiento "en la infracción del deber de cooperar con el fin de procurar la plena eficacia de una obligación".

37 Abeliuk, R., Las obligaciones, Editorial Jurídica de Chile, Santiago, 2003, p. 153. Similar en Ramos, R., De las obligaciones, Lexis Nexis, Santiago, 2004, p. 287. 
mayor, el hecho del tercero y el hecho y la culpa del acreedor ${ }^{38}$. En esa línea, considera que si el acreedor ha creado algún obstáculo que dificulte al deudor en el cumplimiento se configuraría mora del acreedor, para lo que necesariamente debería obrar con culpa. Como se ve, nuevamente el análisis es estrecho, pues ni siquiera explicita la necesidad de cooperación o colaboración del acreedor, circunscribiéndola solo a no poner obstáculos en el cumplimiento del deudor. Similar razonamiento es el de Fernando Fueyo, quien se refiere explícitamente a la cooperación del acreedor, también situándola en la mora del acreedor, la que define como: "el retraso del cumplimiento motivado por la falta de cooperación indispensable del acreedor, o bien su negativa a la aceptación de la prestación que le ofrece el deudor" ${ }^{39}$. Más adelante afirma que en muchas oportunidades el acreedor no es un elemento pasivo que solo se limita a recibir el pago, pues debe llevar a cabo actos materiales para posibilitar el cumplimiento, como "abrir sus bodegas aun a horas no laborales o en días feriados, proporcionando una cuadrilla de hombres para descargar, disponiendo de una grúa-horquilla, o herramientas o iluminación, etc.” ${ }^{\circ}$.

Desde otra perspectiva, Carlos Ducci parece referirse a la falta de colaboración del acreedor, en su estudio respecto de la culpa del acreedor en la responsabilidad contractual $^{41}$. Propone elaborar una causal de exoneración a partir de lo que se establece en el art. 2330, ubicada en sede de ilícitos civiles, pero que es de aplicación general, más otras normas diseminadas en el Libro IV, como los arts. 1590, 1600, 1827, 1859, 1860, 1861, 1925, 1926, 1927, 1928, 1933, 1938, 1959, 1961, 1975, etc. De todas ellas, infiere Ducci, el criterio del Código Civil es exonerar al deudor si su incumplimiento se debe total o parcialmente a causa extraña, lo que incluye la culpa del acreedor, pues en la responsabilidad contractual debe tomarse en cuenta la culpa de ambas partes, lo que sería aplicación de la ejecución de buena fe que se impone a los contratantes de acuerdo con el art. 1546. Esta postura, sin embargo, se aparta bastante de nuestra exposición, no solo por contener, igual que en los casos anteriores, una concepción reduccionista acerca del comportamiento que debe desplegar el acreedor durante el contrato, sino porque, en nuestra opinión, esas consecuencias no solo dicen relación con la configuración de una causal de exoneración total o parcial de responsabilidad del deudor, por el contrario, pueden constituir un caso de incumplimiento contractual del propio acreedor, que es lo que se trata de probar.

En algunos estudios nacionales más recientes se ha aludido a la colaboración del acreedor a propósito de varias materias; así, sobre incumplimiento contractual y

${ }^{38}$ Rodríguez, P., Responsabilidad contractual, Santiago, Editorial Jurídica de Chile, 2003, p. 199. Liga, luego, la culpa del acreedor con la mora del acreedor, tornándolas prácticamente sinónimas, destacando que ella se configura cuando el acreedor pone obstáculos al deudor para que cumpla, por lo que se debería admitir que hay "un deber de no enervar u obstruir la ejecución de la conducta debida por el deudor". p. 203.

39 Fueyo, F., Cumplimiento e incumplimiento de las obligaciones, Editorial Jurídica de Chile, Santiago, 2004 , p. 453.

${ }^{40}$ Fueyo, F., cit., p. 454. Agrega que a veces los actos pueden traducirse en actos jurídicos o administrativos, todos los cuales son “conducentes a la misma idea de colaboración indispensable”, p. 454.

${ }^{41}$ Ducci, C., cit., pp. 485 ss. 
remedios contractuales en el ámbito de la $\mathrm{CISG}^{42}$, y con ocasión de la carga de mitigar las pérdidas ${ }^{43}$. Desde otra perspectiva, pero también considerándola una carga, se ha tratado a la colaboración del acreedor en un estudio relativo a las cargas que pesan en el acreedor en el marco del contrato de seguro de responsabilidad civil. En él se cita como ejemplo el caso de las obligaciones de dar, para cuyo cumplimiento es necesario que el acreedor reciba la cosa; se agrega que, en ese sentido, se trataría de una carga, ya que su cumplimiento solo interesa al acreedor, pues no se concuerda con el hecho de que el cumplimiento pueda interesar también al deudor, de manera que si no puede cumplir por causa ajena, quedaría liberado de la misma ${ }^{44}$. Entre estos trabajos, hay dos análisis más específicos respecto de la colaboración del acreedor; en uno de ellos se exponen las diversas teorías que concerniente a la naturaleza jurídica ha elaborado la doctrina extranjera, para concluir que de acuerdo con las circunstancias la cooperación del acreedor a veces es carga, y a veces deber. Este estudio añade nutrida referencia a los posibles orígenes de la figura en el derecho romano ${ }^{45}$. El segundo trabajo constituye una reflexión inicial referida a la colaboración del acreedor con énfasis en la constitución en mora del acreedor, aunque acepta que en algunos casos la inobservancia de la misma puede dar lugar a responsabilidad contractual por parte del acreedor ${ }^{46}$.

\section{MANiFESTACIONES DEL DEBER DE COLABORACIÓN EN LOS CONTRATOS CIVILES: DESDE LOS CASOS, A LA NATURALEZA DE DEBER FUNCIONAL O SECUNDARIO DE CONDUCTA}

La determinación de si la colaboración del acreedor constituye una carga contractual o un deber inserto en el contrato, no es baladí. En efecto, en el primer caso ello supone reconocer que el comportamiento que debe desplegar el acreedor es solo en su

${ }^{42}$ Vidal, A., "El incumplimiento contractual y los remedios de que dispone el acreedor en la compraventa internacional”, en Revista chilena de derecho, vol. 33, n 3, 2006, pp. 454 s. La Convención, señala Vidal, contempla cargas para el acreedor, como la de comunicación y de conducta material que debe ejecutar, lo que constituye una manifestación de que en el marco de la CISG, ambas partes deben someter su conducta a las exigencias del estándar de lo razonable; agrega que el acreedor debe contribuir con su conducta a que los efectos del incumplimiento sean lo menos gravosos para el deudor incumplidor.

43 Vidal, A., "La carga de mitigar las pérdidas del acreedor y su incidencia en el sistema de remedios por incumplimiento", en Estudios de derecho civil III. Jornadas nacionales de derecho civil, Valparaíso, 2007, Legal Publishing, Santiago, 2008, pp. 436 s.

${ }^{44}$ Lagos, O., Las cargas del acreedor en el seguro de responsabilidad civil, Editorial MAPFRE S.A., Madrid, 2006. p. 34.

${ }^{45}$ San Martín, L., "Sobre la naturaleza jurídica de la 'cooperación' del acreedor al cumplimiento de la obligación: la posición dinámica del acreedor en la relación obligatoria, como sujeto no solo de derechos sino también de cargas y deberes", en Revista de derecho Universidad de Concepción, Concepción, n's 225-226, año LXXVII, 2009, pp. 135-196.

46 Aedo, C., "Cargas o deberes en la posición contractual del acreedor, con especial referencia a su mora de recibir", en Colección Estudios de derecho civil en bomenaje a la profesora Inés Pardo de Carvallo, Ediciones Universitarias de Valparaíso, Valparaíso, 2008, pp. 281 y 303. 
propio beneficio, pues si no coopera el deudor no podrá cumplir la prestación en su favor, de manera que el deudor no estaría facultado para exigir su cumplimiento. Si, por el contrario, se erige como un verdadero deber al interior del contrato, sería factible sostener que la inobservancia a la colaboración debida es un incumplimiento contractual, permitiendo al deudor ejercitar todos los derechos que derivan de la infracción al contrato. Nuestra posición es que la correcta calificación jurídica de la colaboración del acreedor se lleva a cabo desde los grupos de casos en que ella es necesaria, a partir de ello es posible argumentar que, atendidas las consecuencias que se producen para ambas partes contratantes si el acreedor no colabora, se trata de un deber funcional o secundario de conducta.

\section{Los casos}

Si bien hay algunas propuestas de sistematización de casos en que se requiere de la colaboración del acreedor ${ }^{47}$, optamos por seguir un modelo de sistematización que solo tiene por finalidad considerar la mayor o menor complejidad con que se presentan las relaciones contractuales durante la etapa de ejecución del contrato, por ende, este esquema únicamente persigue ilustrar las distintas manifestaciones que puede adoptar la colaboración o cooperación del acreedor en el cumplimiento del contrato.

a. Primer grupo de casos: la negativa a recibir el pago de la obligación por parte del acreedor

Siguiendo la línea de la doctrina extranjera ${ }^{48}$, somos de la opinión que no siempre el pago tiene la naturaleza de negocio jurídico y, en particular, de una convención extintiva ${ }^{49}$. En algunos casos no será más que un simple hecho, más concretamente, la

${ }^{47}$ Como Caballero Lozano, que distingue entre cooperación inicial, como la necesidad de que el acreedor lleve a cabo la elección acordada en las obligaciones alternativas; concurso coetáneo, que se manifestaría, por ejemplo, en los créditos documentarios, pues el acreedor debe presentar el documento para hacer valer el crédito; y las situaciones en que la colaboración se manifiesta en los momentos finales de la convención, que serían los más numerosos, pues refieren a la simple recepción o toma de posesión de un bien por parte del acreedor. Caballero, J., cit., pp. 107 s. Cabanillas, en cambio, distingue entre cargas contractuales heterónomas y cargas negociales, en las primeras sitúa a la carga de facilitación de la liberación del deudor y de colaboración para que el deudor pueda ejecutar la prestación. Cabanillas, A., cit., p. 72.

48 Así, entre los autores que consideran que la naturaleza del pago está supeditada a la naturaleza de la obligación. Ennecerus, L., Kipp, T., Wolff, M., Tratado de derecho civil, tomo II, vol. $1^{\circ}$ Doctrina general. Derecho de obligaciones, Bosh, Casa Editorial Barcelona, Barcelona, 1954, pp. 304 s. Puig Peña, F., Tratado de derecho civil español. Obligaciones y contratos. Teoría general de la obligación, Revista de Derecho Privado, Madrid, 1951, p. 161.

${ }^{49}$ En Chile, una opinión análoga es la del profesor Vial del Río, quien considera que en el caso de las obligaciones de hacer y no hacer no habría una convención, pues no estaríamos en presencia de una transferencia del dominio. Vial, V., La tradición y la prescripción extintiva como modo de adquirir el dominio, Editorial $\mathrm{P}$. Universidad Católica de Chile, Santiago, 2003, p. 377. Rodríguez Grez, en cambio, citando igualmente a Vial, lo contradice, pues considera que en estos casos habría una verdadera presunción simplemente legal de cumplimiento, pues si se hace o no hace el hecho prometido, la calificación corresponde al acreedor, quien 
ejecución del hecho debido. En seguida, es posible advertir que las situaciones en que se requiere que el acreedor colabore para que el deudor pueda cumplir, ya sea recibiendo efectivamente el pago, o no obstaculizándolo, es un ámbito que debe ser analizado con una mirada eminentemente práctica, toda vez que hay circunstancias en que naturalmente se requiere de la concurrencia del acreedor para que el deudor pague, y en otras no. Si, por ejemplo, hay una obligación dineraria en que se ha acordado que el pago se realice mediante el depósito en una cuenta corriente, cuyos datos han sido proporcionados anticipadamente, no se requiere de la colaboración del acreedor para que el deudor lleve a cabo los depósitos respectivos, sin perjuicio que, en caso que el acreedor obstaculice el pago, por ejemplo, cerrando la cuenta corriente, se produciría una infracción al deber de colaboración por no permitir la recepción del pago, en la línea que analizamos. De ahí que los casos relevantes para efectos de este estudio son aquellos en que, en los hechos, no hay forma en que el deudor pueda cumplir sin la aceptación de pago concreta del acreedor, generándose consecuencias perjudiciales para el primero, así, en las situaciones en que el acreedor debe necesariamente concurrir presencialmente y con su voluntad a recibir el pago, como generalmente ocurre con la entrega de una especie o cuerpo cierto. También incluimos en este grupo de casos a aquellos en que el deudor de obligación de hacer no puede cumplir, debido a que atendida la naturaleza de la prestación, se requiere de la comparecencia del acreedor, y ella no se produce. Aquí se halla una gran variedad de situaciones, por ejemplo, si un cliente reserva una habitación en un hotel y no se presenta el día y hora de la reserva ${ }^{50}$; o se contrata a un escultor o pintor para que esculpa o pinte la figura del acreedor, este deberá posar para él y luego no concurre a las citas fijadas al efecto, citado al inicio de estas líneas ${ }^{51}$; o se solicita una entrevista para ser atendido por un médico, abogado, arquitecto o, en general, de profesionales que presten servicios de la más diversa naturaleza, y luego el cliente no va a la reunión. Lo que tienen en común todas ellas, es que la colaboración se presenta por medio de un comportamiento específico: recibir el pago que ofrece el deudor, recepción que puede requerirse una sola vez, o en varias oportunidades, como ocurrirá en contratos de tracto sucesivo y en algunos de ejecución diferida.

b. Segundo grupo de casos: colaboración del acreedor que se manifiesta durante la ejecución de contratos de mayor complejidad

Designamos como contratos de mayor complejidad a aquellos en que la colaboración del acreedor se presenta de forma diversa a la sola recepción del pago que se le ofrece, pues supone una variedad de comportamientos que el acreedor deberá desplegar durante el desarrollo del contrato, y que permiten que la contraparte lo ejecute. Estos comportamientos que debe llevar a cabo el acreedor pueden estar expresamente establecidos en el

de considerar que hay incumplimiento, podrá reclamar de ello. Rodríguez, R., Extinción convencional de las obligaciones. Volumen 1, Editorial Jurídica de Chile, Santiago, 2006, pp. 127 y 177.

${ }^{50}$ Larenz, K., Derecho de obligaciones, Editorial Revista de derecho privado, Madrid, 1958, p. 376.

${ }^{51}$ Cabanillas, A., cit., p. 206. 
contrato, o no encontrarse explicitados, lo que no significa que la naturaleza del deber de colaboración sea distinta; en ambas situaciones la cooperación del acreedor se constituye como un deber secundario, instrumental o funcional de conducta del acreedor, de cuya inobservancia derivan iguales consecuencias jurídicas para las partes contratantes. Así, en contratos que contemplan obligaciones primordiales de hacer, como el mandato, o el contrato de construcción, entre otros, es usual que atendida la duración de la convención, la naturaleza de las obligaciones involucradas o la entidad económica del contrato, las partes hayan incluido deberes de colaboración, como la necesidad de que el acreedor de una obligación de hacer deba proporcionar ciertas instrucciones al deudor para que la ejecute; o se indique que el acreedor proveerá al deudor del plan de trabajo que deba seguir; o que pondrá a disposición del deudor ciertos bienes, como maquinarias, espacios físicos, e incluso personal de su dependencia; o que el acreedor será quien provea de determinadas especificaciones técnicas; o que será el acreedor quien llevará a cabo ciertos trámites administrativos, etc. También se aprecia en contratos en que la o las obligaciones del deudor son de dar, como ocurre en el caso de algunos contratos de suministro de bienes. Algo similar se visualiza en un caso resuelto por nuestros tribunales, referido a un incumplimiento de contrato de ejecución de obras celebrado entre una empresa y el Servicio de Vivienda y Urbanismo de la décima región. En este caso demandó la empresa constructora por incumplimiento de contrato, solicitando la indemnización de los daños que le produjo la no entrega de los terrenos en que se debían ejecutar las obras en condiciones idóneas, toda vez que les fueron entregados con escombros y sin contar con la factibilidad de los servicios básicos, todo ello trajo aparejado un retraso en la ejecución de las obras y mayores costos que los que se habían previsto ${ }^{52}$.

\section{La colaboración del acreedor constituye un deber secundario o funcional en la relación contractual}

En la concepción contemporánea del derecho de contratos se ha puesto especial énfasis al resguardo de los intereses del acreedor. Se afirma que la relación obligatoria debe ser contemplada no solo desde la perspectiva del deber, "cuyo cumplimiento libera al deudor, sino desde la más amplia (que no contradice a la anterior) de resultado de satisfacción del interés del acreedor" ${ }^{53}$. Ello es efectivo, atendido una concepción pragmática de contrato, con la que suscribimos. Sin embargo, no podemos obviar que el contrato, en particular el bilateral, constituye un entramado de intereses, debiendo ser considerados los de ambas partes contratantes. De ahí que una manifestación de esta consideración se encuentra precisamente en estos casos en que el cumplimiento de las

52 No obstante, en este caso la demanda fue rechazada en primera instancia, fallo confirmado por la Corte de Apelaciones de Puerto Montt, debido a la falta de pruebas suficientes que acreditaren que efectivamente el retraso en el cumplimiento se debió a la no entrega de los terrenos en condiciones idóneas por parte del servicio. La Corte Suprema rechazó la casación en el fondo en fallo de fecha 29 de noviembre de 2004, causa rol 2773-04.

${ }^{53}$ Morales, A., cit., pp. 21 y 30. Vidal, A., cit., pp.439 ss. 
obligaciones de una parte se encuentra supeditada al comportamiento que despliegue la otra. Empero, toda vez que hemos calificado a la colaboración del acreedor como un deber inserto en la relación contractual, técnicamente no es suficiente que la ejecución de la o las prestaciones por parte del deudor dependan de que el acreedor efectivamente coopere, sino que lo determinante es que sin dicha cooperación los intereses del propio deudor se vean afectados. Por ello es que, a juicio nuestro, la inobservancia de la colaboración debida genera dos órdenes de efectos: en primer término, aquellos efectos que se producen en la propia obligación del deudor; y luego, los efectos referidos al incumplimiento contractual del acreedor.

Ahora bien, cuando afirmamos que la inobservancia al deber de colaboración del acreedor acarrea que los intereses del deudor sean afectados, aludimos a los otros intereses de los contratantes que pueden verse comprometidos con la relación contractual, y que no son aquellos que las partes pretenden obtener con la misma-que, citando a Cane, identificamos con las nociones de objetivos ventajosos- ${ }^{54}$. Nos referimos pues, a la amplia gama de intereses de las partes, patrimoniales o extrapatrimoniales, que pueden resultar lesionados por la inobservancia de las obligaciones a que da lugar la convención. En una primera aproximación, reconozcamos nuevamente la gran variedad de acepciones que tiene el término en cuestión ${ }^{55}$, como asimismo su amplitud. Con todo, para efectos de identificar los intereses del deudor que pueden verse menoscabados por la inejecución del deber de colaboración, utilizaremos el significado que se le confiere al analizar el tópico del daño en sede de responsabilidad civil y que suele situársela en la vieja disputa respecto del alcance de esa noción, que discurre entre la vulneración a un derecho subjetivo o de un interés jurídicamente protegido; en este segundo sentido, el interés estaría constituido por "un bien jurídico digno de cautela" 56 . Es, entonces, en

${ }^{54}$ Cane, P., Anatomía del derecho de daños, Flandes Indiano, Santiago, 2011, p. 105. Acerca de la variedad de intereses $c f r$. Webb, Ch., "Performance and compensation: an analysis of contract damages and contractual obligation", en Oxford Journal of Legal studies, Oxford, vol. 26, No 1, 2006, pp. 42 s.

55 En esa línea, es factible recordar que Von Ihering identifica a los derechos con los intereses jurídicamente protegidos. Agrega que "el derecho no aplica a esas ideas una medida exclusivamente económica, como el dinero o el valor pecuniario. Existen otros intereses además de la fortuna que deben garantirse al hombre”. Von Ihering, R., El espíritu del derecho romano, Casa editorial Bailly-Bailliere, Madrid s/f., p. 365. "Cualquiera que sea la diversidad del interés que presenten los diversos derechos, todo derecho establecido es la expresión de un interés reconocido por el legislador que merece y reclama su protección. Los intereses se transforman a medida que cambian los intereses de la vida; así, intereses y derechos son en cierto modo históricamente paralelos. La correlación, sin embargo, no es absoluta”, p. 368. Von Ihering, R., La lucha por el derecho, Editorial Araujo, Buenos Aires, s/f. p. 89. Con relación a la jurisprudencia de intereses, "La meta final de la jurisprudencia de los tribunales y de la resolución judicial del caso es la 'satisfacción de las necesidades de la vida, de las apetencias y tendencias apetitivas, tanto materiales como ideales, existentes en la comunidad jurídica”, Estas “apetencias y tendencias apetitivas” las denominamos, explica Heck, intereses; y la peculiaridad de la jurisprudencia de intereses consiste en "intentar no perder de vista esta meta final, incluso en cada operación particular, en cada formación del concepto”. Larenz, K., Metodología de la ciencia del derecho, Ariel Derecho, Barcelona, 2010, p. 71. Gorla, G., El contrato. Problemas fundamentales tratados según el método comparativo y casuístico, Bosch, Barcelona, 1959, pp. $270 \mathrm{~s}$.

56 Barros, E., Tratado de responsabilidad extracontractual, Editorial Jurídica de Chile, Santiago, 2006, p. 220. "Sea dicho interés sustrato de un derecho subjetivo, bien provenga de situaciones objetivas que no 
este último alcance que utilizamos el término “interés o intereses" del deudor, los que se ven perjudicados a consecuencia de la inobservancia de la colaboración debida por la contraparte ${ }^{57}$. Este contenido que se confiere a la expresión intereses del deudor, se encuentra en la línea de lo establecido en el §241 (2) del BGB que ya hemos transcrito, y que en lo pertinente establece que dentro de la relación obligatoria las partes se encuentran también obligadas a respetar los derechos, bienes jurídicos e intereses de la otra parte. Esta norma, recordemos, la citamos al momento de analizar el progresivo reconocimiento de la colaboración del acreedor por las legislaciones extranjeras, porque la relación contractual contiene, además de las principales prestaciones, ciertos deberes secundarios de conducta, entre ellos se sitúa la colaboración del acreedor. Ahora, y consecuencial con lo anterior, el énfasis lo ubicamos en que cada contratante debe necesariamente respetar los intereses de la otra parte ${ }^{58}$. Si el acreedor no observa la colaboración que de él se espera, y con ello resultan vulnerados intereses del deudor, estamos en presencia de un incumplimiento contractual por parte de dicho acreedor, con todas las consecuencias que ello conlleva. A pesar de que en nuestro derecho no hay una norma análoga al §241 (2) del BGB, la consideración a los intereses lesionados del deudor por la inobservancia de la colaboración debida no es más que aplicación en sede contractual del principio según el cual no se puede lesionar la esfera de intereses ajenos, ya que, de ser vulnerados, surge como consecuencia jurídica la de indemnizar el daño ocasionado. En ese sentido, no cabe duda de que tales daños no pueden quedar sin reparación, toda vez que derivan de un incumplimiento contractual, por lo que procedería el remedio indemnizatorio, conforme a las reglas generales. Es decir, desde el binomio constituido por: incumplimiento contractual por inobservancia del deber de colaboración/daño que

proporcionan un derecho de tal índole”. Bueres, A., Derecho de daños, Editorial Hammurabi, Buenos Aires, 2001, p. 483. Barros, E., "La responsabilidad civil como derecho privado. Notas sugeridas por la reseña de C. Rosenkrantz al Tratado de responsabilidad extracontractual”, en Revista Estudios Públicos, Santiago, No 112 , primavera 2008, p. 314. Ennecerus, L., Kipp, T., Wolff, M., cit., p. 85. Betti, E., cit., p. 171. Es posible señalar que los Principios de derecho europeo de la responsabilidad civil -PETL- definen en el artículo 2:101, al daño resarcible, como "el perjuicio material o inmaterial a un interés jurídicamente protegido".

57 "Si haber causado un daño ha de brindar razones moralmente relevantes para imponer responsabilidad y conceder una indemnización, el interés dañado debe crear un fundamento moralmente relevante para respetarlo". "En síntesis, si el hecho de sufrir un daño constituye el ingrediente que falta en la fórmula de la responsabilidad, entonces dañar debe ser más que perjudicar cualquier interés de un individuo; debe ser calificado de un modo moralmente relevante. El modo normal de calificar intereses es distinguiendo los legítimos de los ilegítimos. Dañar es perjudicar intereses legítimos”. Coleman, J., Riesgos y daños, Marcial Pons, Madrid, 2010, p. 283.

${ }^{58}$ Zimmermann, R., cit., p. 59. Markesinis, B., Unberath, H., y Jonhston, A., cit., p. 127. Por ello es que se observa que con la reforma del 2001 al BGB, por primera vez se consagra expresamente una obligación general abstracta en los términos que ya indicamos -respetar los derechos e intereses de la otra parte-, lo que dependerá del contenido de la relación de obligación. Así, se valida la previa y bien establecida práctica de los tribunales de considerar que el interior del contrato existe, por ejemplo, una obligación que implica protección, aunque no se hace desaparecer el establecimiento del amplio principio del neminem laedere del derecho de daños, que está gobernado por la cláusula general más específica del $§ 823$ (1) BGB, que limita el deber de protección a ciertos derechos. p. 126. Ehmann, H., y Sutschet, H., cit., p. 104. 
ese cumplimiento acarrea al deudor, procede la aplicación de los remedios contractuales de conformidad a la normativa general, entre ellos, el indemnizatorio.

\section{El RESUlTAdo: EL INCUMPLIMIENTO DEL DEBER DE COLABORACIÓN DEL ACREEDOR COMO UN INCUMPLIMIENTO CONTRACTUAL}

Para efectos de este trabajo seguimos la tendencia del derecho contractual contemporáneo, que sustenta que el incumplimiento está constituido por cualquier desviación del programa contractual ${ }^{59}$, lo que incluye la inobservancia de deberes secundarios insertos al interior del contrato, como lo es la colaboración debida por parte del acreedor. Nos parece que a la luz de nuestro derecho es perfectamente posible arribar a esa conclusión, atendida la amplitud con que se encuentran redactadas muchas de las normas pertinentes contenidas en el CCCh, como el art. 1556, que alude al cumplimiento imperfecto, en una fórmula suficientemente laxa como para situar una enorme gama de incumplimientos contractuales. Pero, además, es necesario adicionar que en el título XIV, párrafo $1^{\circ}$, sobre el pago efectivo en general, hay algunas disposiciones que llevan a aceptar que no solo hay incumplimiento contractual si el deudor no cumple con las obligaciones principales o primordiales, sino también en el caso de inobservancia a los deberes complementarios o secundarios. Así, la expresión utilizada por el art. 1568 “de lo que se debe”, al definir el pago, admite incorporar en la noción de cumplimiento todo aquello que las partes deban en virtud del contrato, lo que incluye a estos deberes complementarios de la relación contractual; con igual significado, el art. 1569 señala a renglón seguido que "el pago se hará bajo todos los respectos en conformidad al tenor de la obligación”, y en el segundo inciso agrega que "el acreedor no podrá ser obligado a recibir otra cosa que lo que se le deba". La palabra "deba" es de amplio alcance, se debe todo lo que queda incorporado en la relación contractual, sin distinciones: se deben obligaciones principales o primordiales y deberes complementarios, como la colaboración que debe prestar el acreedor contractual. Si no se paga lo que se debe, hay incumplimiento contractual. Agregado a esto, es perfectamente posible articular esta interpretación de las normas, vinculándolas a otras disposiciones fundamentales en sede contractual. En efecto, en la definición de cláusula penal del art. 1535 se infiere que la obligación se asegura ante incumplimientos de cualquier naturaleza, ya se trate de no ser ejecutada, o de ser retardada, lo que es concordante con la historia de su establecimiento ${ }^{60}$. De otra parte, no cabe duda que la vastedad del art. 1545 permite a las partes obligarse tanto a prestaciones primordiales como funcionales, lo que luego se ve reforzada por la norma contenida en el art. 1560 del código civil. En consecuencia, toda vez que la colaboración del acreedor constituye

${ }^{59}$ Morales, A., cit., pp. 29 s.

${ }^{60}$ En efecto, en los Proyectos de 1842 y 1847, la norma no contemplaba la expresión "o de retardar", la que aparece en el Proyecto de 1853. Repertorio. Acerca de la función de la cláusula penal ante el incumplimiento, cfr. Corral, H., La "cláusula penal". Función y eficacia del contrato penal en el derecho chileno, Editorial Jurídica de Chile, Santiago, 2012. 
un deber funcional, su inobservancia constituye un incumplimiento contractual a la luz de nuestro derecho, incumplimiento que generalmente será imperfecto.

De modo tal, que la inobservancia de la debida colaboración del acreedor genera dos órdenes de efectos: en primer lugar, en lo que refiere a la o las obligaciones que el deudor dejó de cumplir debido a la inobservancia de la colaboración debida de la contraparte, nos parece que se origina la inexigibilidad de la obligación del deudor ${ }^{61}$; y en segundo término, se sitúa al propio acreedor en una hipótesis de incumplimiento contractual. Nos interesa resaltar este segundo grupo de efectos, toda vez que hemos calificado a la infracción a la debida colaboración por parte del acreedor como un caso de incumplimiento contractual, usualmente, imperfecto.

Toda vez que estamos en presencia de un incumplimiento contractual, el deudor tendrá la posibilidad de ejercitar los remedios derivados de dicho incumplimiento del acreedor. Entre ellos, no se divisa obstáculo jurídico alguno para que el deudor pretenda obtener el cumplimiento del deber de colaboración del acreedor. En efecto, es posible encontrar casos en que se ha demandado judicialmente el cumplimiento, especialmente en aquellos en que la falta de colaboración refiere a la no recepción de pago, más que en los que la colaboración del acreedor se materializa en forma más compleja ${ }^{62}$. Sin

${ }^{61}$ A nuestro entender, este grupo de efectos configuran la denominada mora del acreedor, que tiene dos elementos: el supuesto fáctico y las consecuencias jurídicas. El supuesto fáctico de la mora creditoris está constituido por todos aquellos casos en que se requiere de la colaboración del acreedor para que el deudor pueda cumplir con su o sus obligaciones -ya sea que dicha colaboración se materialice en la necesidad de que reciba el pago que se le ofrece, o bien, que la colaboración se requiera de otras formas- y no la presta. Por ello, es que la mora del acreedor constituye una causal de inexigibilidad de la obligación del deudor, inexigibilidad que será total o parcial, de acuerdo con la incidencia que tenga dicha colaboración en el cumplimiento de la misma. Este efecto implica que si el deudor no ejecuta el contrato debido a la inobservancia de la colaboración por el acreedor, dicho deudor no se sitúa en una hipótesis de incumplimiento contractual, lo que tiene directa incidencia en el destino de los remedios contractuales que podría pretender ejercer el acreedor que no colaboró. Así, por ejemplo, el acreedor no está facultado para demandar el cumplimiento de dicha obligación, precisamente, porque mientras él no coopere, la obligación del deudor es inexigible. De igual forma, no procede hacer responsable al deudor de los eventuales perjuicios que haya padecido el acreedor debido a su propia mora, configurándose como una causal de exoneración de responsabilidad civil del deudor, distinta y autónoma del caso fortuito. Prado, P., "La colaboración del acreedor en los contratos civiles, de acuerdo al ordenamiento jurídico chileno”, Tesis Doctoral.

${ }^{62}$ Como en STS español de 1 de septiembre de 2009, en que se demanda el pago de la parte de precio adeudada por la compradora, en virtud de un contrato preparatorio de compraventa, contrato de compraventa definitivo que no se ha podido celebrar, a pesar de que el prometiente vendedor ha estado dispuesto a ello, a tal punto que el notario designado por ella tenía la escritura preparada para que los compradores la firmaran, y estos no prestaron la debida colaboración para documentar públicamente el contrato. Hay que hacer presente que el fallo de casación dejó sin efecto parcialmente el fallo, en lo que respecta a los montos que se ordena pagar a las demandadas. Un caso especialmente demostrativo del hecho de que atendido el interés del deudor contractual, le resulta conveniente solicitar el cumplimiento de la colaboración debida, se denota en aquellas situaciones en que tal colaboración consiste en recibir el pago que la deudora está dispuesta a efectuar; así, se visualiza en STS español de fecha 18 de octubre de 2007. En la causa se demanda por la empresa fabricante de unos termos, para que la compradora de los mismos reciba la cantidad completa respecto de la que se había celebrado el contrato, pues solo fueron recibidos 28.400 de 60.000. La defensa de la compradora se centró en que la adquisición de los restantes termos estaría supeditada al éxito de la campaña publicitaria que se llevara a efecto, por lo que se trataba de una obligación sujeta a esa condición suspensiva, la que falló. La 
embargo, hay algunas razones que pueden incidir en que no se opte habitualmente por la acción de cumplimiento, entre ellas, que debido a la extensa duración de las causas en nuestro actual procedimiento civil ${ }^{63}$, no siempre satisfaga al deudor intentar obtener el cumplimiento de la colaboración debida, para que se le permita, luego, ejecutar el contrato en los términos acordados. En segundo lugar, que atendida la naturaleza de funcional o instrumental que, postulamos, tiene el deber de colaboración, lo más probable es que su inobservancia se conocerá cuando el propio acreedor pretenda demandar por incumplimiento al deudor, y este se defienda fundado en que no le fue posible ejecutar el contrato, debido a la infracción del acreedor. En tal caso, surge a la luz el primer grupo de efectos que hemos resaltado, en orden a que la obligación del deudor contractual se torna inexigible mientras el acreedor no coopere.

De ahí que el remedio indemnizatorio sea, probablemente, el más apropiado, toda vez que, como hemos dejado establecido, por medio de él es posible solucionar de forma más adecuada aquellos efectos que trae aparejada la inobservancia del deber de colaboración y que implican una lesión a los otros intereses del deudor contractual, que es el supuesto que nos lleva a calificar a la colaboración de deber contractual en los grupos de casos que se han identificado.

En efecto, hay varias manifestaciones de los daños padecidos por el deudor debido al incumplimiento del deber de colaboración. A vía meramente ejemplar, el reembolso de los mayores gastos en que ha incurrido el deudor por el hecho de no haber cumplido con su propia obligación. Acerca de este ítem es posible hacer dos comentarios: el primero, que no solo es aplicable a los casos en que dichos gastos se originan por la conservación y custodia de la cosa que el acreedor se ha negado recibir en pago de una obligación de dar, sino que también abarca cualquiera otra expensa en que incurra el deudor ante la negativa de recibir el pago de obligaciones de otra naturaleza, como aparece corroborado incluso por la jurisprudencia nacional ${ }^{64}$. En segundo lugar, que para los autores

sentencia de primera instancia que acoge la demanda de la vendedora, expresa que las partes han atribuido al acreedor "un deber de colaboración en la ejecución del pago o cumplimiento. Este deber de colaboración tiene una enorme trascendencia a la hora de configurar la mora creditoris o mora en que incurre el acreedor por oponerse o retardar maliciosamente la prestación del deudor. Así, pues, la cuestión planteada pasa necesariamente por resolver en qué momento preciso o bien dentro de qué plazo debía la demandada Caja España dirigir a Bacab Marketing S.L. la obligada comunicación, manifestándole el lugar y momento de la entrega de los 31.600 termos 'restantes'; pues en tal momento incurrió Caja España en la situación de mora creditoris, con la doble consecuencia de excluir, por un lado, la mora debitoris o mora del deudor, y por otra parte, de responder de los daños que el retraso en el ordenado desenvolvimiento del contrato haya ocasionado a la contraparte". Se acoge así la demanda, ordenando a la compradora a hacerse cargo de los 31.600 termos restantes y a indemnizar de perjuicios a la demandante vendedora, sentencia confirmada en apelación, y el recurso de casación interpuesto por la demandada, rechazado en todas sus partes.

${ }^{63}$ Como lo reconoce el propio Mensaje del Ejecutivo con el que se inicia el Proyecto de ley de nuevo código procesal civil, del 12 de marzo de 2012, Mensaje 004-360, p. 13.

${ }^{64}$ Precisamente esa base de la indemnización de perjuicios es lo que se demandó en causa caratulada "Empresa constructora e inmobiliaria Confe Ltda. con Comsa de Chile S.A.", sentencia de la Corte de Apelaciones de Santiago de 14 de septiembre de 2010, No descriptor MJJ24837, en que la demandante solicita el pago de los mayores costos que le habría ocasionado la realización de obras extraordinarias en la construcción de dos plantas de tratamiento de aguas servidas, montos ocasionados, entre otras razones que 
que sustentan que la colaboración del acreedor constituye una carga contractual, este ítem es reembolsable fundado en el enriquecimiento sin causa o en argumentos basados en la equidad ${ }^{65}$. No concordamos con esta opinión, pues tales gastos se materializan es una disminución patrimonial efectiva, que puede mejor encuadrarse en la categoría de daño emergente, atendido lo dispuesto en el art. $1556 \mathrm{CCCh}$, de modo que, como probablemente ocurrirá, si hay además otros intereses del deudor que se ven menoscabados, este reembolso constituirá la base mínima de la indemnización de perjuicios que el deudor está facultado a demandar. A la vez, nos parece que, atendida la naturaleza del contrato en que está incorporado el deber de colaboración, posiblemente constituirá un perjuicio previsto.

En seguida, hay que preguntarse si sería calificable como daño indemnizable la especial situación patrimonial en que se encuentra un deudor que no se ha liberado del vínculo obligacional, debido a la inobservancia del deber de colaboración del acreedor, por ejemplo, si el acreedor no recibe el pago, el patrimonio del deudor reflejará la existencia de un pasivo, lo que podría afectar su capacidad crediticia. Por consiguiente, surge el cuestionamiento en torno a si la mantención de la relación contractual puede erigirse, por sí misma, como un daño resarcible. La respuesta, nos parece, se encuentra en lo que hemos venido señalando, en orden a que habrá derecho a obtener el resarcimiento del daño, en tanto la no desvinculación contractual afecte otros intereses del deudor. Esto es, la sola permanencia de la relación contractual con el acreedor no constituye un daño resarcible, debido a que no necesariamente se reunirán los requisitos del daño indemnizable; solo en la medida que efectivamente se reúnan tales requisitos, podría dar lugar a ser resarcido aquel deudor que no ha podido apartarse del contrato.

Finalmente, desde luego que hay otra serie de daños susceptibles de ser demandados, dependiendo de la naturaleza de la colaboración incumplida y del contrato en que ella incide, como se ve reflejado en el siguiente caso conocido por nuestros tribunales de

aduce, porque la empresa mandante no habría entregado las especificaciones técnicas correctas al momento de iniciarse la relación contractual. Es admisible señalar que en la causa la actora demanda la restitución de los valores en que incurrió por obras extraordinarias, sin embargo, de acuerdo con la sistematización que adoptamos en este trabajo, estas sumas serían la base de la indemnización de perjuicios, derivada de la falta de colaboración de la contraparte durante la vigencia del contrato. La demanda se rechaza por falta de prueba. También como base de la indemnización de perjuicios, se demanda reconvencionalmente en sentencia arbitral CCAM de 29 de julio de 2010, causa Rol 1087-2009; en ella la demandante reconvencional solicita se declare el incumplimiento de contrato de arquitectura, suministro y construcción, debido a que la demandada reconvencional habría introducido durante la vigencia del contrato varias modificaciones al proyecto original, lo que le impidió ejecutar el contrato de la forma prevista, solicita que se declare que ella ha cumplido con sus obligaciones surgidas del contrato; que la demandada reconvencional pague ciertas cantidades de dinero, correspondientes a estados de pago pendientes; restitución de las cantidades retenidas de los estados de pago correspondientes a las obras ordinarias o extraordinarias; obras adicionales no pagadas; gastos generales por permanencia extendida y por la ejecución de las obras adicionales y extraordinarias pagadas y no pagadas; utilidad correspondiente a las mismas obras señaladas; restitución de los mayores recursos invertidos como consecuencia de las modificaciones introducidas por la demandada; costos financieros por no haber sido pagada oportunamente en sus créditos en contra de la mandante. La sentencia declara el término del contrato, y acoge parcialmente la demanda y la demanda reconvencional.

${ }^{65}$ Cabanillas, cit., p. 185. 
justicia: en los contratos en que se encarga la ejecución de una obra o la prestación de un servicio, una manifestación característica del incumplimiento del deber de colaboración durante la vigencia del contrato, es aquel en que el contratante que encarga la obra o contrata el servicio, no permite que el deudor ingrese a las dependencias de la primera, para que este pueda cumplir con sus obligaciones. En un contrato de confección de obra material en que se encarga la habilitación de un local para el funcionamiento de un restaurante-pizzería, la mandante interpone demanda de resolución con indemnización de perjuicios, pero la empresa demandada alega que fue la propia actora quien le impidió ingresar en la obra para cumplir el contrato, ante ello la demandada reconviene, solicitando se declare la resolución por incumplimiento de la actora, con indemnización de perjuicios ${ }^{66}$. Acerca de los perjuicios posibles de ser resarcidos, ciertamente que los mayores desembolsos realizados por el retraso de las obras - pago de materiales, remuneraciones de los trabajadores- es un ítem que debería resarcirse; como asimismo, el lucro cesante derivado de la imposibilidad de cumplir con otros compromisos que ya se habían adquirido por la empresa.

\section{BIBLIOGRAFÍA}

Abeliuk, R., Las obligaciones, Editorial Jurídica de Chile, Santiago, 2003.

AEdo, C., "Cargas o deberes en la posición contractual del acreedor, con especial referencia a su mora de recibir", en Colección Estudios de derecho civil en homenaje a la profesora Inés Pardo de Carvallo, Ediciones Universitarias de Valparaíso, Valparaíso, 2008.

Albaladejo, Manuel, Derecho civil II. Derecho de obligaciones, Edisofer S.L., Madrid, 2004.

Alessandri, A., De los contratos, Editorial Jurídica de Chile, Santiago, 2010.

BArros, E., Tratado de responsabilidad extracontractual, Editorial Jurídica de Chile, Santiago, 2006. BArros, E., "La responsabilidad civil como derecho privado. Notas sugeridas por la reseña de C.

Rosenkrantz al "Tratado de responsabilidad extracontractual”, en Revista Estudios Públicos, Santiago, $\mathrm{N}^{\circ} 112$, primavera 2008.

BetTi, E., Teoría general de las obligaciones, Editorial Revista de derecho privado, Madrid, 1969. Bueres, A., Derecho de daños, Editorial Hammurabi, Buenos Aires, 2001.

Caballero, J., La mora del acreedor, Bosh Editor S.A., Barcelona, 1992.

Cabanillas, A., Las cargas del acreedor en el derecho civil y en el mercantil, Editorial Montecorvo S.A., Madrid, 1988.

Cane, Peter, Anatomía del derecho de daños, Flandes indiano, Santiago, 2011.

Cattaneo, G., La cooperazione del creditore all’ adempimento, Dott. A. Giuffre-Editore, Milán, 1964.

66 "Pepes Pizza con Lazcano Zamora", sentencia de la Corte Suprema de 13 de agosto de 2009, $\mathrm{N}^{\circ}$ descriptor MJJ 21110. En esta causa la demandada opone excepción de incumplimiento de contrato y demanda reconvencionalmente resolución con indemnización de perjuicios. La sentencia de primera instancia acoge la demanda principal y rechaza la reconvencional. La de segunda instancia revoca el fallo recurrido, y rechaza también la demanda principal. El recurso de casación en el fondo se rechaza, fundado en que no se habría acreditado el incumplimiento de la demandada, estando acreditado el incumplimiento de la demandante, por lo que correspondía acoger la excepción de incumplimiento contractual, no obstante ello, no se declara la resolución del contrato. 
Coleman, J., Riesgos y daños, Marcial Pons, Madrid, 2010.

Colin, A., y Capitant, H., Curso elemental de derecho civil. Teoría general de las obligaciones, Reus S.A., Madrid, 1987.

Corral, H., La "cláusula penal". Función y eficacia del contrato penal en el derecho chileno, Editorial Jurídica de Chile, Santiago, 2012.

Díez Picazo, L., "El contenido de la relación obligatoria", Separata, Instituto Nacional de Estudios Jurídicos, en Anuario de Derecho Civil, fasc. II, 1964.

Díez Picazo, L., Fundamentos del derecho civil patrimonial. Introducción a la teoría del contrato, Civitas, Thomson Reuters, Madrid, 2009.

Ducci, C., "La culpa del acreedor en la responsabilidad contractual", en Tavolari, R., Doctrinas esenciales de derecho civil. Obligaciones, Editorial Jurídica de Chile, Santiago, 2009.

Hedemann, J.W, Derecho de obligaciones, Editorial Revista de Derecho Privado, Madrid, 1958.

Ehmann, H., y Sutschet, H., Modernización del derecho alemán de obligaciones, Universidad Externado, Bogotá, 2006.

Eeidenmuller, H., Faust, F., Grigoleit, H., Jansen, N., Wagner, G., Zimmermann, R., "El marco común de referencia para el derecho privado europeo", en Anuario de Derecho Civil, Madrid, No LXII, fasc. IV, 2009.

Ennecerus, L., Kipp, T., Wolff, M., Tratado de derecho civil. Doctrina general. Derecho de obligaciones, Bosh, Casa Editorial Barcelona, Barcelona, 1954.

Falzea, A., L'offerta reales e la liberazione coattiva del debitore, Giuffré, Milán, 1947.

Fueyo, F., Cumplimiento e incumplimiento de las obligaciones, Editorial Jurídica de Chile, Santiago 2004.

García, M., Lecciones de derecho civil II. Teoría general de las obligaciones y contratos, McGraw-Hills, Madrid, 1995.

Gorla, G., El contrato. Problemas fundamentales tratados según el método comparativo y casuístico, Bosch, Barcelona, 1959.

LAGOS, O., Las cargas del acreedor en el seguro de responsabilidad civil, Editorial MAPFRE S.A., Madrid, 2006.

Lamarca, A., El hecho del acreedor y la imposibilidad de la prestación, Publicaciones del Real Colegio de España, Bolonia, 2001.

Larenz, K., Derecho de obligaciones, Editorial Revista de Derecho Privado, Madrid, 1958.

Larenz, K., Metodología de la ciencia del derecho, Ariel Derecho, Barcelona, 2010.

López, J., Los contratos. Parte general. Primera Ed., Editorial Jurídica de Chile, Santiago, 1988.

Markesinis, B., Unberath, H., Jonhston, A., The german law of contract. A comparative, traitase, Hart Publishing, Oxford, Portland, Oregon 2006.

Martínez de Aguirre, C., en Cámara, S. (coord.), Derecho privado europeo, Colex, Madrid, 2003.

Medicus, D., Tratado de las relaciones obligacionales, Bosch, Barcelona, 1995.

Morales, A., La modernización del derecho de obligaciones, Civitas, Madrid, 2006.

Morales, A., Incumplimiento del contrato y lucro cesante, Civitas, Madrid, 2010.

PRINCIPIOS UNIDROIT sobre los contratos comerciales internacionales 2010, International Institute for the Unification of Private Law, Roma, 2007.

Puig Peña, F., Tratado de derecho civil español. Obligaciones y contratos. Teoría general de la obligación, Revista de Derecho Privado, Madrid, 1951.

Ramos, R., De las obligaciones, Lexis Nexis, Santiago, 2004.

Rodríguez, P., Responsabilidad contractual, Editorial Jurídica de Chile, Santiago, 2003.

Rodríguez, P., Extinción convencional de las obligaciones, Editorial Jurídica de Chile, Santiago, 2006.

Rogel, C., (coordinador) Código europeo de contratos. Libro I: De los contratos. Libro II, Título I: De la compraventa, Editorial Reus S.A., Madrid, 2009.

SAN Martín, L., "Sobre la naturaleza jurídica de la "cooperación” del acreedor al cumplimiento de la obligación: la posición dinámica del acreedor en la relación obligatoria, como sujeto 
no solo de derechos sino también de cargas y deberes", en Revista de Derecho Universidad de Concepción, n's 225-226, año LXXVII, enero-junio, julio-diciembre 2009.

VIal, V., Manual del derecho de obligaciones en el código civil chileno, Universidad Andrés Bello, Santiago, 2003.

VIDAL, A., "El incumplimiento contractual y los remedios de que dispone el acreedor en la compraventa internacional”, en Revista Chilena de Derecho, Santiago, vol. 33, No 3, 2006.

VIDAL, A., "La carga de mitigar las pérdidas del acreedor y su incidencia en el sistema de remedios por incumplimiento", en Estudios de derecho civil III. Jornadas nacionales de derecho civil, Valparaíso, 2007, LegalPublishing, Santiago, 2008.

Von Ihering, R., El espíritu del derecho romano, Casa editorial Bailly-Bailliere, Madrid s/f.

Von Ihering, R., La lucha por el derecho, Editorial Araujo, Buenos Aires, s/f.

Von Thur, A., Tratado de las obligaciones, Editorial Comares S.L., Granada, 2007.

WebB, Ch., "Performance and compensation: an analysis of contract damages and contractual obligation", en Oxford Journal of Legal studies, Oxford, vol. 26, No 1, 2006.

Zimmermann, R., El nuevo derecho alemán de obligaciones. Un análisis desde la Historia y el Derecho comparado, Bosch, Barcelona, 2008. 
